\title{
Effect of Self-study component towards Students Performance in Chemical Engineering Coursework: Case Study of Chemical Engineering
}

\author{
Sirisha Nallakukkala ${ }^{1}$, Soumen Panda ${ }^{2}$ \\ ${ }^{1}$ Assistant Professor, Department of Chemical Engineering, B.M.S. College of Engineering, Bengaluru - 560019, India \\ sirisha.nallakukkala@gmail.com
}

\begin{abstract}
Introducing the self-study component has provided benefits in the student gaining knowledge as well as learning capability. Through current initiatives of novel technical know-how sources and further, advancing time of teaching strategies, revitalizing status of learning and instructing approaches are in advancement, for learners as well as teachers. To upgrade learning outcomes in self-study, especially during engineering, learning with just hands-on by guidance may not be adequate. Inspiration derives from evaluating the students learning. This paper associates accomplishment of program outcomes (POs) and Course Outcomes (COs) for core chemical engineering course with and without incorporating self-study component. At last, it is discovered that more level of result is accomplished through the usage of self-study. The primary discoveries from self-study indicated good progress concerning knowledge, sorting out, the time allotted in the laboratory, innovative reasoning/thinking and student perception. This paper portrays and analyzes systems and usage of conventional (interpretive) with open-ended experiments for two subjects, including chemical reaction engineering and process control engineering subjects. The courses are communicated to the
\end{abstract}

\section{Sirisha Nallakukkala}

${ }^{1}$ Assistant Professor, Department of Chemical Engineering, B.M.S. College of Engineering, Bengaluru - 560019, India sirisha.nallakukkala@gmail.com students by several instruction practices, namely classroom teaching, laboratory experimentations, seminar sessions and project assignments. Every topic is planned with particular COs, and every individual $\mathrm{CO}$ is mapped to the respective PO. The accomplishment of COs is measured by evaluating students. Their performance is measured/calculated and studied using Microsoft Excel. In this way, it is found that there is better attainment obtained by implementing the self-study component. The level of accomplishment can be varied depending on the difficulty level of the course and proficiency of the student. It is seen that the learner's performance is improved by incorporating the self-study component.

\section{Introduction}

Significant general objectives in academia teaching are, for instance, problem-solving skills, thinking ability, critical thinking, readiness to discover novel thoughts, thoughts or concepts as well as the improvement of an imaginative mindset [1]. Outcome-Based Education (OBE) has been executed in The Faculty of Engineering, B.M.S College of Engineering, Bengaluru, India that requires students being practical. Hence faculties are cheered towards implementing inventive teaching instruction methods such as Project-Based Learning, Active Learning, Cooperative Learning, Independent Learning and others [2]. Many of these instruction techniques are integrated into the laboratory of chemical engineering curriculum design. Earlier conventional laboratory for this course required undergraduates to execute numerous experiments per semester. Students were 
given a week timeframe for submitting written reports and were corrected only on submission of their written reports. Presently, the laboratory course method has been improved to include dynamic participation of undergraduates to improve as well as nurture students' abilities [3]. Employing OBE, prior training is altered, with the innovative methodology being implemented. Teaching through the active participation of undergraduates by giving two kinds of report writing, namely group work and individual as well as a spoken presentation of open-ended experiment themes or issues. Undergraduates were ranked depending on the written reports both individual as well as in a team, giving puzzles and by the spoken presentation [4]. This furthermore helps in attaining the engineering knowledge goals which emphasize the critical thinking ability and engineering development of solutions [5]. This methodology moreover develops undergraduates' proper utilization of time plus motivates societal exchange that needs the usage of soft skill abilities [6]. Information and Communication Technology centred teaching stands an innovative development in collecting information at the present existing learning situation. Development of internet-based education has immensely reached current education training [7]. At the present novel model of computer-based instruction is attained by employing virtual laboratories in university teaching. This type of expertise influences a better-personalized knowledge which meets rural and city instructive requirements through better flexibility plus thereby decrease anxieties related to a time period. Network tools immeasurably supported the present training and knowledge learning practices[8]. Simulation laboratories deliver varied investigation of concepts from end to end diverse modules namely by means of near imitation of physical research laboratory understanding with the help of computer graphics, that serve as a pictorial or diagrammatic representation accepting a methodology or else investigating on more highlighted manner [9]. Through simulation the major significant stages of experimentation, undergraduates can practice a substitute hands-on experience by means of the procedure listed thus relating to what they have done in the laboratory by stimulating interaction[10]. By doing this, it suggests directions towards decreasing reoccurrence of errors such as this one limits the student regarding the different common errors committed during working hands-on or working using apparatus in laboratory otherwise during executing the experimentation by way of rearranging the experimental set up [11]. The present instruction view, web-based expertise deliver distinctive benefits aimed at planning new technical based handouts plus emerging, extremely communicating studentinstructor association[12-13]. In this article, it is shown that introduction of open-ended experiment and virtual lab modules through the self-study component played an endless enthusiasm from student's perspective which improved student's approach and outlook towards effective practical learning and better accomplishment of program outcomes.

\section{Methodology}

To perform the analysis of the effect of Self-study component towards learner's performance in Chemical Engineering Course 2 subjects were taken, namely Chemical Reaction Engineering (CRE) and Process Control Engineering (PCE). CRE is offered to fifth-semester students and PCE to sixth-semester students. These courses are called integrated courses as they are tied up with theory - 3 credits, lab component - 1 credit according to the curriculum. After introducing self-study component, they are renamed as an integrated course by adding extra two credits to the newly designed curriculum. So the credits to the core course has been increased from 4 to 6 credits. Set of 70 students were allocated with different activities. Activities being open ended experiments, hands on experiences using MS Excel, presentation on industrial application based topics related to course content and perform a virtual lab experiment. Open-ended experiment in the sense that new alternative experiment an extension or relating to what they do during their normal lab sessions weekly is framed based on the available resources and students were allowed to choose the topics and perform them by taking their own initiative and creativity under minimal guidance of the professor. Most of the experiments were designed to do comparative analysis over the conventional laboratory experiments with different chemicals. Students were given hands-on session on usage of MS Excel and later were probed to perform tedious lab calculations such as plotting data and finding the area under a curve. Purpose of giving hands-on session is to make sure they develop computing and analyzing skills with an understanding of limitations to complex engineering problems. This activity showed to be satisfying the program outcome linked to life- long learning, selecting and applying modern engineering information technology (IT) tool. Presentation is 
another activity which is linked under self-study hence for CRE course under self-study component virtual lab and presentation is given and under PCE open-ended experiment and presentation were suggested to students. Each of these courses was floated with two components as part of self-study. Towards, analyzing the function of Chemical Engineering, simulation-based research laboratory now incorporating undergraduate's knowledge capability plus presenting that one by way of an efficient instructional tool in the chemical engineering curriculum. Virtual lab practice improves independent as well as directed instructive techniques. By means of connecting students through practicing virtual labs alongside conventional laboratory by performing experiments, performed better by means of virtual labs. Practicing, investigation carried, and reviews show that virtual labs stay noteworthy essentials in adaptive learning circumstances.

Regarding presentation, each group is given a topic related to application features in today's requirement of sustainability. Students were assessed based on their technical content delivery, effective communication, time management, and teamwork. This activity too proved to satisfy program outcomes related to individual and teamwork, communicate effectively and usage of the modern tool.

\section{Analysis}

As measure of curriculum and course design assessment, course outcomes of the respective courses, namely CRE and PCE are mapped to the individual primary program outcomes. Course Outcome valuation stays the essential valuation of the subjects that specific undergraduate curriculum proposes. This measures the learning knowledge of a student in addition to instruction efficiency. Learning results relates to the Course outcomes to that particular course as it is arranged through the concerned teacher who is delivering the respective course work. Mapping of CO to PO is prepared by means of investigating the syllabus. These mapping stages suggest the involvement, of course, to attain a particular PO for a specific course. There are certain advantages of outcome mapping, like how the courses add value to the success of program outcomes, by raising students achievement in meeting the program outcomes. On the other hand it also reveals gaps in the curriculum design, decreases the quantity of time involved for formative assessment required as much attention can be moved towards program assessment project based learning. The overview of Program Outcomes (POs) is mentioned in Table 1. Mapping of course outcomes to particular program outcome for the undergraduate study is listed below in Table 2 where Course outcomes are mapped to a specific program outcome in such a way that they satisfy respectively. The student is evaluated for selfstudy component on two modules, open-ended experiment and presentation for PCE course as specified below with well-defined rubrics in Table 3, 4 and 5. Similarly for CRE based on two modules namely virtual lab experimentation and presentation. There is total of 64 students in class enrolled for CRE. They were divided into 15 groups with each group of 4 people. Each group is supposed to complete the module by performing virtual lab experiment. Throughout this process, students were allowed to converse, teamwork and deliberate among peers meant for the comprehensive growth of laboratory research till the finish of submission of the technical report. This course is a core chemical engineering course, so it has a lab component attached to it. Apart from conventional laboratory-based approach, students were assigned a virtual lab experiment. In both the cases, the results were tabulated and determined as it is in accordance with the application theme and apparatus accessibility. For both cases, the application levels were categorized into theoretical, investigational work, comparing/inference analysis and description writing. However in a virtual lab it has different units that deal with the chemical/biochemical methods, in addition, comprise simulators, applications and case studies intended on leading the undergraduates to realize developments in a much better and convenient manner. Virtual experiments, relate to the picturing of the laboratory of simple processes connected to the industry practices, besides through the aid of remote observing of laboratory experimentations. Furthermore, this virtualization tool has a discussion forum which enables the students to raise a question or problem they are facing while performing the simulation. Additionally, this tool will give proper assistance to students to prepare better for their laboratory lessons. CRE is related to separation techniques that include purification of elements of reactors beforehand and afterwards. The complete behaviour will be led by the optimization of overall association of components. The students are assigned in the field of kinetics, design and reactor process that is to be used in homogeneous and heterogeneous reactions. They have to figure out kinetics, modelling associated with 
laboratory investigations to analyze kinetic parameters, the order of reaction and activation energies. The above metioned information is required to figure out mathematical equations which shows the effect of temperature, the composition of reactants that are mainly used in industries. Similarly, PCE students were given a presentation module as part of self-study. For the presentation, each group is assigned with a topic related to different kinds of controllers used in industries for specific application, control loop mechanism implemented in industries. By this, students get to work hands-on on first-order and second-order systems; determine their time constants and response for standard inputs. They are informed to figure out the working mechanism of final control elements, valve characteristics and different types of valves used in industries. The flow control and temperature controllers mechanism used in the industry gives them an understanding about the tuning of proportional integral derivative (PID) controller to get the desired response in a flow or temperature control

\section{Table 1 : Engineering graduate Attributes /Program Outcomes}

\begin{tabular}{|l|l|}
\hline PO1 & Engineering Knowledge \\
\hline PO2 & Problem Analysis \\
\hline PO3 & Design/development of the solution \\
\hline PO4 & Conduct investigations of complex problems \\
\hline PO5 & Modern tool usage \\
\hline PO6 & The engineer and society \\
\hline PO7 & Environment and sustainability \\
\hline PO8 & Ethics \\
\hline PO9 & Individual and teamwork \\
\hline PO10 & Communication \\
\hline PO11 & Project Management and finance \\
\hline PO12 & Life - long learning. \\
\hline
\end{tabular}

Table 2 :As Per the Curriculum Mapping of CO to PO for Theory-Tutorial/ Lab/ Self-Study Components for the course Chemical Reaction Engineering

\begin{tabular}{|c|c|l|c|}
\hline $\begin{array}{c}\text { Course } \\
\text { Title }\end{array}$ & \multicolumn{1}{|c|}{ Course Outcome } & $\begin{array}{c}\text { Programme } \\
\text { Outcome }\end{array}$ \\
\hline $\begin{array}{c}\text { Chemical } \\
\text { Reaction } \\
\begin{array}{c}\text { Engineeri } \\
\text { ng (CRE) }\end{array}\end{array}$ & CO1 & $\begin{array}{l}\text { Formulate and analyze rate equations } \\
\text { for different reactions using a } \\
\text { suitable mechanism for reaching a } \\
\text { sustainable conclusion }\end{array}$ & PO2 \\
\hline
\end{tabular}

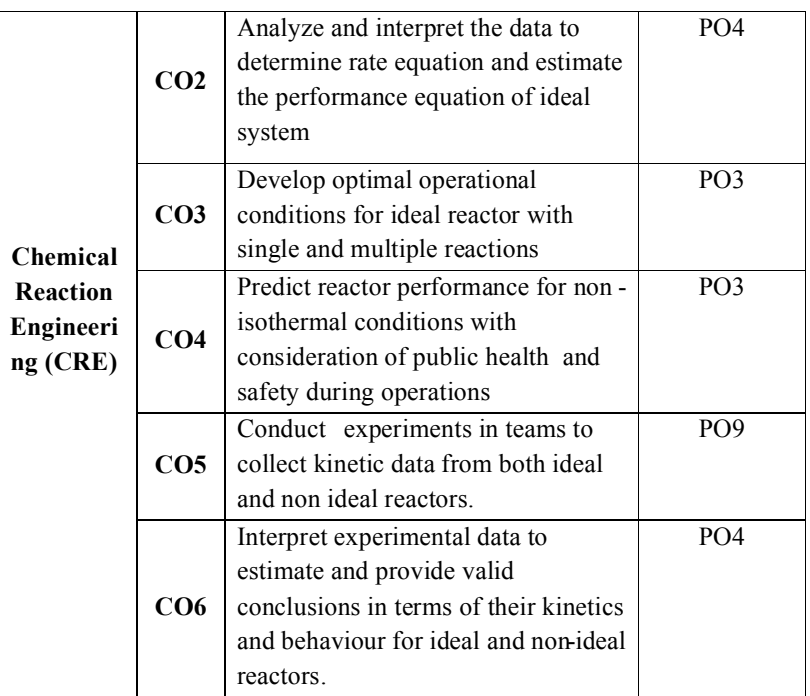

Table 3 : As Per the Curriculum Mapping of CO to PO for Theory-Tutorial/ Lab/ Self-Study Components for the course Process Control Engineering

\begin{tabular}{|c|c|c|c|}
\hline $\begin{array}{c}\text { Course } \\
\text { Title }\end{array}$ & \multicolumn{2}{|r|}{ Course Outcome } & $\begin{array}{c}\text { Programme } \\
\text { Outcome }\end{array}$ \\
\hline \multirow[t]{5}{*}{$\begin{array}{l}\text { Process } \\
\text { Control } \\
\text { Engineering }\end{array}$} & CO1 & $\begin{array}{l}\text { Formulate the transfer } \\
\text { function, predict response of } \\
\text { first and second order systems } \\
\& \text { identify an appropriate } \\
\text { instrument for the } \\
\text { measurement of temperature } \\
\text { and pressure. }\end{array}$ & PO4 \\
\hline & $\mathrm{CO2}$ & $\begin{array}{l}\text { Select a suitable controller } \\
\text { and evaluate the response } \\
\text { behaviour of the controllers to } \\
\text { model complex engineering } \\
\text { problems with an } \\
\text { understanding of the } \\
\text { limitations. }\end{array}$ & PO5 \\
\hline & $\mathrm{CO3}$ & $\begin{array}{l}\text { Verify the stability of control } \\
\text { systems to understand the } \\
\text { impact of the professional } \\
\text { engineering solutions and } \\
\text { demonstrate the knowledge of } \\
\text { need for sustainable } \\
\text { development. }\end{array}$ & PO7 \\
\hline & CO4 & $\begin{array}{l}\text { Conduct experiments in } \\
\text { teams to collect data for } \\
\text { different functional inputs to } \\
\text { various processes with and } \\
\text { without controllers. }\end{array}$ & PO9 \\
\hline & CO5 & $\begin{array}{l}\text { Interpret experimental data to } \\
\text { estimate and provide valid } \\
\text { conclusions which encourages } \\
\text { to recognize need to engage in } \\
\text { independent and lifelong } \\
\text { learning. }\end{array}$ & PO12 \\
\hline
\end{tabular}


Table 4 : Rubrics for presentation

\begin{tabular}{|c|c|c|c|c|}
\hline $\begin{array}{l}\text { Evaluation } \\
\text { Parameter }\end{array}$ & $\begin{array}{l}\text { Excellent } \\
91-100 \%\end{array}$ & $\begin{array}{l}\text { Good } \\
61-90 \%\end{array}$ & $\begin{array}{l}\text { Fair } \\
41-60 \%\end{array}$ & $\begin{array}{l}\text { Poor } \\
0-40 \%\end{array}$ \\
\hline $\begin{array}{l}\text { Technical } \\
\text { Content } \\
\text { (2 Marks) }\end{array}$ & $\begin{array}{l}\text { Incorporated all the } \\
\text { relevant technical } \\
\text { information and } \\
\text { similarities required } \\
\text { to explain the topic }\end{array}$ & $\begin{array}{l}\text { Incorporated } \\
\text { technical } \\
\text { information } \\
\text { required to explain } \\
\text { the topic }\end{array}$ & $\begin{array}{l}\text { Technical } \\
\text { information can be } \\
\text { comprehensive and } \\
\text { slightly improve the } \\
\text { description }\end{array}$ & $\begin{array}{l}\text { Technical } \\
\text { content } \\
\text { inadequate } \\
\text { for the } \\
\text { explanation. }\end{array}$ \\
\hline $\begin{array}{l}\text { Preparation of } \\
\text { slides/ Videos/ } \\
\text { Animations } \\
\text { (2 Marks) }\end{array}$ & $\begin{array}{l}\text { Draw the viewers' } \\
\text { attention with good } \\
\text { visual appeal and } \\
\text { presentation of } \\
\text { information. } \\
\text { Incorporated videos } \\
\text { and animations. }\end{array}$ & $\begin{array}{l}\text { Good arrangement } \\
\text { of information. } \\
\text { Incorporated } \\
\text { videos/animations }\end{array}$ & $\begin{array}{l}\text { Conveyed the } \\
\text { information, but } \\
\text { there is a possibility } \\
\text { for enhancement. }\end{array}$ & $\begin{array}{l}\text { Must } \\
\text { improve. } \\
\text { Jumbled then } \\
\text { aligning not } \\
\text { satisfactory }\end{array}$ \\
\hline $\begin{array}{l}\text { Team Work } \\
\text { (1 Marks) }\end{array}$ & $\begin{array}{l}\text { Encourages the } \\
\text { team although } \\
\text { contributing as a } \\
\text { member }\end{array}$ & $\begin{array}{l}\text { Showed attention in } \\
\text { the complete work } \\
\text { process of the team }\end{array}$ & $\begin{array}{l}\text { Contributed his part } \\
\text { as a member }\end{array}$ & $\begin{array}{l}\text { Disconnect } \\
\text { with the other } \\
\text { members }\end{array}$ \\
\hline $\begin{array}{l}\text { Communication } \\
\text { Skills } \\
\text { (2 Marks) }\end{array}$ & $\begin{array}{l}\text { Presenter follow a } \\
\text { logical sequence } \\
\text { and delivers an } \\
\text { explanation. }\end{array}$ & $\begin{array}{l}\text { Host adapts logical } \\
\text { order and then fails } \\
\text { to explain. }\end{array}$ & $\begin{array}{l}\text { Host does not adapt } \\
\text { logical order but } \\
\text { delivers the } \\
\text { message. }\end{array}$ & $\begin{array}{l}\text { Host does not } \\
\text { adapt logical } \\
\text { order nor } \\
\text { delivers the } \\
\text { message. }\end{array}$ \\
\hline $\begin{array}{l}\text { Time } \\
\text { Management } \\
\text { (1 Marks) }\end{array}$ & $\begin{array}{l}\text { Ability to } \\
\text { effectively space the } \\
\text { slides within the } \\
\text { time-bound }\end{array}$ & $\begin{array}{l}\text { Completed within } \\
\text { the timeframe, on } \\
\text { the other hand, has } \\
\text { to speed up through } \\
\text { last points to finish } \\
\text { within the } \\
\text { timeframe }\end{array}$ & $\begin{array}{l}\text { Required substantial } \\
\text { extra time or wound } \\
\text { up much before the } \\
\text { time limit }\end{array}$ & $\begin{array}{l}\text { Presenter } \\
\text { didn't } \\
\text { complete on } \\
\text { fixed time } \\
\text { and doesn't } \\
\text { complete the } \\
\text { work carried } \\
\text { out evidently. }\end{array}$ \\
\hline $\begin{array}{l}\text { Understanding } \\
\text { of the content } \\
\text { (Viva-Voce) } \\
\text { (2 Marks) }\end{array}$ & $\begin{array}{l}\text { Answers everything } \\
\text { in a manner that } \\
\text { shows a systematic } \\
\text { understanding of the } \\
\text { theme }\end{array}$ & $\begin{array}{l}\text { Capability to } \\
\text { answer maximum } \\
\text { questions. }\end{array}$ & $\begin{array}{l}\text { Ability to address } \\
\text { only few questions. }\end{array}$ & $\begin{array}{l}\text { Unable to } \\
\text { answer well. }\end{array}$ \\
\hline
\end{tabular}


Table 5 : Rubrics for virtual lab

\begin{tabular}{|c|c|c|c|c|}
\hline $\begin{array}{l}\text { Evaluation } \\
\text { Parameter }\end{array}$ & $\begin{array}{l}\text { Excellent } \\
91-100 \%\end{array}$ & $\begin{array}{l}\text { Good } \\
61-90 \%\end{array}$ & $\begin{array}{l}\text { Fair } \\
41-60 \%\end{array}$ & $\begin{array}{l}\text { Poor } \\
0-40 \%\end{array}$ \\
\hline $\begin{array}{l}\text { Scientific method: } \\
\text { A wide range of } \\
\text { factors is analyzed } \\
\text { that relate to the key } \\
\text { understandings of } \\
\text { the topic. Plans and } \\
\text { predictions are } \\
\text { effectively supported } \\
\text { (2 Marks) }\end{array}$ & $\begin{array}{l}\text { It includes well } \\
\text { written purpose, } \\
\text { hypothesis, } \\
\text { resources, } \\
\text { procedures, } \\
\text { observations, } \\
\text { and an apt } \\
\text { conclusion. }\end{array}$ & $\begin{array}{l}\text { It includes purpose, } \\
\text { hypothesis, } \\
\text { materials, } \\
\text { resources, } \\
\text { observations, and } \\
\text { result. }\end{array}$ & $\begin{array}{l}\text { Report is mostly } \\
\text { complete, organized; } \\
\text { on the other hand, } \\
\text { one or two specifics } \\
\text { are omitted. } \\
\text { Procedure theory } \\
\text { and definitions are } \\
\text { outlined but lack } \\
\text { clarity. }\end{array}$ & $\begin{array}{l}\text { Report is } \\
\text { mostly } \\
\text { incomplete, } \\
\text { difficult to } \\
\text { understand, } \\
\text { has errors. } \\
\text { Minimal } \\
\text { reference to the } \\
\text { purpose of the } \\
\text { experiment. }\end{array}$ \\
\hline $\begin{array}{l}\text { Introduction : } \\
\text { Information section } \\
\text { is very clearly } \\
\text { introduced. There } \\
\text { are strong relations } \\
\text { applicable to the } \\
\text { concept. Excellent } \\
\text { definitions of } \\
\text { subject-specific } \\
\text { terminology. } \\
\text { (2 Marks) }\end{array}$ & $\begin{array}{l}\text { Information } \\
\text { section is } \\
\text { clearly introduced. } \\
\text { There are } \\
\text { appropriate } \\
\text { relations to } \\
\text { applicable } \\
\text { concept. Well } \\
\text { explained, clear } \\
\text { definitions of } \\
\text { subject-specific } \\
\text { terminology. }\end{array}$ & $\begin{array}{l}\text { Information section } \\
\text { is introduced. There } \\
\text { are relations to } \\
\text { applicable concept, } \\
\text { most definitions of } \\
\text { subject-specific } \\
\text { terminology. }\end{array}$ & $\begin{array}{l}\text { Short introduction to } \\
\text { information section. } \\
\text { limited relations to } \\
\text { the applicable } \\
\text { concept, few } \\
\text { definitions of } \\
\text { subject-specific } \\
\text { terminology. }\end{array}$ & $\begin{array}{l}\text { No or } \\
\text { inadequate } \\
\text { Information } \\
\text { section. No } \\
\text { links to } \\
\text { relevant } \\
\text { theory. } \\
\text { Incorrect } \\
\text { definitions of } \\
\text { subject- } \\
\text { specific } \\
\text { terminology. }\end{array}$ \\
\hline $\begin{array}{l}\text { Instructions: Clear, } \\
\text { brief, thorough } \\
\text { reasoning of suitable } \\
\text { system; method } \\
\text { exactly outlined. } \\
\text { ( } 1 \text { Marks) }\end{array}$ & $\begin{array}{l}\text { Student answers } \\
\text { each step of the } \\
\text { scientific } \\
\text { method } \\
\text { completely and } \\
\text { accurately. }\end{array}$ & $\begin{array}{l}\text { Student answers } \\
\text { each step of the } \\
\text { scientific method } \\
\text { fairly well and } \\
\text { accurately. }\end{array}$ & $\begin{array}{l}\text { Students partially } \\
\text { answers each step of } \\
\text { the scientific } \\
\text { method, with some } \\
\text { inaccurate details. }\end{array}$ & $\begin{array}{l}\text { Required } \\
\text { work is } \\
\text { incomplete } \\
\text { and } \\
\text { inaccurate. }\end{array}$ \\
\hline $\begin{array}{l}\text { Interactive } \\
\text { Simulator sand } \\
\text { Tools: } \\
\text { High speed high- } \\
\text { performance tools } \\
\text { and simulators. } \\
\text { Capable of } \\
\text { producing high- } \\
\text { quality print work. }\end{array}$ & $\begin{array}{l}\text { Works } \\
\text { extremely well } \\
\text { no problems } \\
\text { with access, } \\
\text { general use or } \\
\text { loading. Fast } \\
\text { interactive } \\
\text { steps. Always } \\
\text { works correctly } \\
\text { and produces }\end{array}$ & $\begin{array}{l}\text { Only minor } \\
\text { difficulties in } \\
\text { access, use and } \\
\text { loading. Occasional } \\
\text { delays between } \\
\text { interactive steps. } \\
\text { Works correctly to } \\
\text { produce accurate } \\
\text { results. Good print, } \\
\text { calculation }\end{array}$ & $\begin{array}{l}\text { Some difficulties in } \\
\text { access, use and } \\
\text { loading. Delays } \\
\text { between interactive } \\
\text { steps. Occasionally } \\
\text { does not work or } \\
\text { produces inaccurate } \\
\text { results. Acceptable } \\
\text { print, simulation and } \\
\text { calculation }\end{array}$ & $\begin{array}{l}\text { Difficult to } \\
\text { access and } \\
\text { use. } \\
\text { Difficulties in } \\
\text { loading and } \\
\text { long delays } \\
\text { between } \\
\text { interactive } \\
\text { steps. Often } \\
\text { does not work }\end{array}$ \\
\hline
\end{tabular}




\begin{tabular}{|c|c|c|c|c|}
\hline $\begin{array}{l}\text { Perform complex } \\
\text { calculations and } \\
\text { simulations } \\
\text { simultaneously. } \\
\text { Ability to post, } \\
\text { respond to and } \\
\text { assess work online. } \\
\text { (1 Marks) }\end{array}$ & $\begin{array}{l}\text { highly accurate } \\
\text { results. } \\
\text { Excellent print, } \\
\text { simulation and } \\
\text { calculation } \\
\text { capacities. }\end{array}$ & $\begin{array}{l}\text { simulation and } \\
\text { calculation } \\
\text { capacities. }\end{array}$ & & $\begin{array}{l}\text { or produces } \\
\text { inaccurate } \\
\text { results. No } \\
\text { print, } \\
\text { simulation or } \\
\text { calculation } \\
\text { abilities. }\end{array}$ \\
\hline $\begin{array}{l}\text { Print } \\
\text { /Charts/graphs/res } \\
\text { ults: } \\
\text { (1 Marks) }\end{array}$ & $\begin{array}{l}\text { Well-presented } \\
\text { high quality } \\
\text { presentation }\end{array}$ & $\begin{array}{l}\text { A clear and concise } \\
\text { chart/graph is } \\
\text { included with all } \\
\text { information } \\
\text { necessary. }\end{array}$ & $\begin{array}{l}\text { A chart/graph is } \\
\text { included. Some data } \\
\text { is missing }\end{array}$ & $\begin{array}{l}\text { The } \\
\text { chart/graph is } \\
\text { included. } \\
\text { Missing a } \\
\text { significant } \\
\text { amount of } \\
\text { information. }\end{array}$ \\
\hline $\begin{array}{l}\text { Conclusion and } \\
\text { Evaluation : } \\
\text { Activity suggests } \\
\text { high student } \\
\text { engagement. } \\
\text { High level } \\
\text { evaluation functions } \\
\text { (2 Marks) }\end{array}$ & $\begin{array}{l}\text { Clear and } \\
\text { concise } \\
\text { Inference } \\
\text { addresses } \\
\text { problem and } \\
\text { information } \\
\text { added. }\end{array}$ & $\begin{array}{l}\text { Inferences exist } \\
\text { current; information } \\
\text { gained is available, } \\
\text { then not clear and } \\
\text { brief. }\end{array}$ & $\begin{array}{l}\text { Omitted certain } \\
\text { portions of } \\
\text { inference. }\end{array}$ & $\begin{array}{l}\text { Omitted } \\
\text { inference } \\
\text { entirely, or it } \\
\text { is imprecise. }\end{array}$ \\
\hline $\begin{array}{l}\text { Interpret and } \\
\text { analyze data: } \\
\text { (1 Marks) }\end{array}$ & $\begin{array}{l}\text { Predict and } \\
\text { communicate in } \\
\text { an extensive } \\
\text { techniques. }\end{array}$ & $\begin{array}{l}\text { Execute and } \\
\text { investigate data and } \\
\text { material with some } \\
\text { representations, } \\
\text { comprising } \\
\text { tables,graphs to } \\
\text { represent and } \\
\text { describe } \\
\text { observations. }\end{array}$ & $\begin{array}{l}\text { Execute and } \\
\text { investigate data plus } \\
\text { material by limited } \\
\text { representations, } \\
\text { including tables, to } \\
\text { represent and } \\
\text { describe and } \\
\text { communicate } \\
\text { observations. }\end{array}$ & $\begin{array}{l}\text { Process data } \\
\text { and } \\
\text { information } \\
\text { using hard } \\
\text { copy only. }\end{array}$ \\
\hline
\end{tabular}

Table 6 : Result Analysis of Students

\begin{tabular}{|l|l|}
\hline $\begin{array}{c}\text { Strategy forthe attainment of } \\
\text { particular PO }\end{array}$ & \multicolumn{1}{c|}{ Justification } \\
\hline No. of students answered $>50 \%$ & $\begin{array}{l}\text { If marks scored by a student are greater than } 50 \% \text { of the total } \\
\text { allotted mark for a particular PO it is considered that PO has been } \\
\text { attained. }\end{array}$ \\
\hline No. of students not attempted & $\begin{array}{l}\text { It is considered that the remaining set of students have not } \\
\text { achieved that particular PO }\end{array}$ \\
\hline
\end{tabular}




\begin{tabular}{|l|l|}
\hline Total marks secured by all students & $\begin{array}{l}\text { Adding up all the marks secured by the students who answered the } \\
\text { particular question }\left(\mathrm{A}_{1}\right)\end{array}$ \\
\hline $\begin{array}{l}\text { Total marks secured by students } \\
\text { who have obtained }>50 \%\end{array}$ & Sum the marks secured by students $\left(\mathrm{A}_{2}\right)$ \\
\hline $\begin{array}{l}\text { Aggregate marks to be secured by } \\
\text { students who attempted }\end{array}$ & Sum of the marks scored by students who have attempted $\left(\mathrm{A}_{3}\right)$ \\
\hline $\begin{array}{l}\text { Percentage accomplishment of } \\
\text { POs for all who attempted }\left(\mathrm{P}_{1}\right)\end{array}$ & $\mathrm{P}_{1}=\frac{\mathrm{A}_{1}}{\mathrm{~A}_{3}} * 100$ \\
\hline $\begin{array}{l}\text { Percentage attainment of POs for } \\
>50 \% \text { attempted }\left(\mathrm{P}_{2}\right)\end{array}$ & $\mathrm{P}_{2}=\frac{\mathrm{A}_{2}}{\mathrm{~A}_{3}} * 100$ \\
\hline
\end{tabular}

Table 7 : Course Outcome and PO Attainment for PCE

\begin{tabular}{|c|c|c|c|}
\hline $\begin{array}{l}\text { Course Outcomes } \\
\text { (CO)/Program Outcome } \\
\text { (PO) }\end{array}$ & $\begin{array}{l}\text { PO attainment by } \\
\text { implementing self- } \\
\text { study }(\%)[A]\end{array}$ & $\begin{array}{l}\text { PO attainment } \\
\text { before } \\
\text { implementing self - } \\
\text { study } \\
(\%)[B]\end{array}$ & $\begin{array}{l}\text { Percenatge } \\
\text { increase by } \\
\text { implementing self- } \\
\text { study }(\%)=(A- \\
B) / B\end{array}$ \\
\hline $\mathrm{CO} 1 \backslash \mathrm{PO} 4$ & 78.25 & 76.15 & 28 \\
\hline $\mathrm{CO} 2 \backslash \mathrm{PO} 5$ & 80.63 & 69.33 & 16 \\
\hline $\mathrm{CO} 3 \backslash \mathrm{PO} 7$ & 82.19 & 75.68 & 09 \\
\hline CO4\PO9 & 94.43 & 81.35 & 16 \\
\hline CO5\PO12 & 96.30 & 79.36 & 21 \\
\hline
\end{tabular}

Table 8 : Course Outcome and PO Attainment for CRE

\begin{tabular}{|c|c|c|c|}
\hline $\begin{array}{l}\text { Course Outcomes } \\
\text { (CO)/Program Outcome } \\
\text { (PO) mapping }\end{array}$ & $\begin{array}{l}\text { PO attainment by } \\
\text { implementing self- } \\
\text { study }(\%)[C]\end{array}$ & $\begin{array}{l}\text { PO attainment } \\
\text { before } \\
\text { implementing self- } \\
\text { study }(\%)[D]\end{array}$ & $\begin{array}{l}\text { Percenatge increase } \\
\text { by implementing } \\
\text { self-study }(\%)= \\
(\mathrm{C}-\mathrm{D}) / \mathrm{D}\end{array}$ \\
\hline $\mathrm{CO} 1 \backslash \mathrm{PO} 2$ & 88.21 & 72.35 & 22 \\
\hline $\mathrm{CO} 2 \backslash \mathrm{PO} 4$ & 84.02 & 68.43 & 23 \\
\hline $\mathrm{CO} 3 \backslash \mathrm{PO} 3$ & 77.02 & 76.19 & 1 \\
\hline CO4\PO3 & 88.52 & 73.35 & 21 \\
\hline CO5\PO9 & 86.52 & 79.32 & 9 \\
\hline CO6\PO4 & 89.56 & 81.23 & 10 \\
\hline
\end{tabular}

system which they can correlate to what they have done in the conventional laboratory. The variations of the approach of students at each phase were notable on various perception (lab, testing and virtual measurement) assigned to students, fixed time arrangement, teacher and supporter role, and the organization of report writing and assessment feedback/observing practices. Throughout presentation, they are asked to assess their peers towards their involvement in the preparation. They are evaluated in terms of problem identification, how they are going to conduct the experiment calculate, analyze and document their findings by interacting in a group. Steps implemented in the virtual lab are the 
responsibilities allocated are larger ones and not directly quantifiable. So they are broken down into smaller tasks called events. After each event, the students have to answer a question, which is either a multiple-choice question or an open-ended query. Development of items to be asked after completion of each task is framed such that they target the specific learning objective. Diverse sorts of questions are famed, such as problems, open-ended questions. Rubrics for assessing the above activities is implemented. Development of the online material is the design methodology, which is given to the students while they are performing the experiment which they can access while experimenting. The students are required to submit the answers to the assessment questions to the instructor once they complete performing the experiment. All these parameters were measured during the last two weeks before the semester ends with the supporting rubrics in Tables 4 $\& 5$ for presentation in PCE and virtual lab in CRE.

Subsequently coming to the presentation, students are asked to present in class based on the assigned topics. These topics dealt on application-oriented, they have to do a literature survey and visit a few industries to get to know what kind of reactors are used in various industries. During this process, students were allowed to converse, work in group and deliberate among peers through the entire practice until accomplishment. Each group is allotted 8 minutes for the presentation and 2 minutes for questions. They are assessed based on the organization of concepts, industrial application of each unit operation and process, communication skills, understanding on the topic, time management and teamwork. The parameters for assessment of presentation module rubrics are in Table 4. The handson expertise is based on still developing the similar existing apparatus as in the subject line of learning objectives and aims, where only the training, virtual realization and knowledge regarding application has been altered with the implementation of self-study. This shows that an undergraduate not only has a thorough acquaintance with the definite undergraduate curriculum they can also have comprehensive flexibility in addition to approval. To accomplish the PO the chemical engineering syllabus is aimed in a way that undergraduates become proficient in all 12 POs through theory, laboratory and self-study. The subjects are imparted to the undergraduates by way of applying numerous instruction approaches, namely classroom based education, laboratory tests, conducting seminar and projects. Every course work is intended with precise $\mathrm{COs}$, then every $\mathrm{CO}$ is mapped to the respective PO. The accomplishment of COs is measured by evaluating student's performance.

\section{Findings And Discussion}

Result analysis is based on total registered students for each of these courses. The performance of students is assessed, as shown in Table 6. Suppose the marks secured by a student are more than $50 \%$ of the total allocated mark for a specific question. In that case, it is reflected that the particular course outcome which is mapped to particular program outcome is accomplished. The result of self-study on undergraduate accomplishment is thought-provoking and eased by a series of other aspects affecting the achievement of the student. Students capability is wisely associated with how the technology; information of knowledge is used as an informative tool. It is also figured that students understand better with self-study component by learning technical content in an interactive manner as well as by visualization using virtual labs. As in this course of Chemical Reaction Engineering with the introduction of conducting and performing virtual experimentation and in Process Control Engineering the implementation of presentation based on industryrelated aspects/problems has empowered students to correlate, analyze, visualize and improve their thinking competency. The introduction of self-study constituent has sustained teachers to get a general impression of students possessing different skills and talent. Using technology and knowledge can assure students, mainly underperforming undergraduates, to study to learn and also perform better. It is noticed that students have attained a higher percentage of COs and POs compared to without the implementation of selfstudy component as represented in Table $7 \& 8$. In table $7 \& 8$ it's perceived that there is slight variation in percentage attainment of $\mathrm{PO} 4$ for $\mathrm{CO} 1$ by implementing self-study. By assigning students to submit a report would enable us to assess their general skills such as technical content and computer literacy and also the practice of research centred information in addition to approaches for analysis and explanation of data and production of evidence to deliver significant inference. For example, in CRE virtual lab, students were asked to perform reaction studies on mixed flow reactor at different temperatures and plot a curve relating temperature versus rate curves. Based on the theory, procedure, simulator, and video available students get an exposure to connect to 
industrial practice and perform the experiment with sound knowledge rather than the conventional laboratory.

Moving towards PCE, for presentation a topic on frying is given where the frying of chips takes in a single step of integrated potato chip manufacture line which handles a series of operations. For a continuous fryer, need to draw an input/output diagram, and state all possible control objectives. Classify the output variables, the manipulated variables and the disturbances for this process. Suggest a possible feedback control loop and justify its role with respect to the control objectives. So in this type student will try to get an overall idea of the process, different types of variables and how he/she can make a feedback control loop for this system. We also can get a better picture regarding the performance of individuals on different abilities they possess as they perform in groups. Abilities like management skills, analyzing
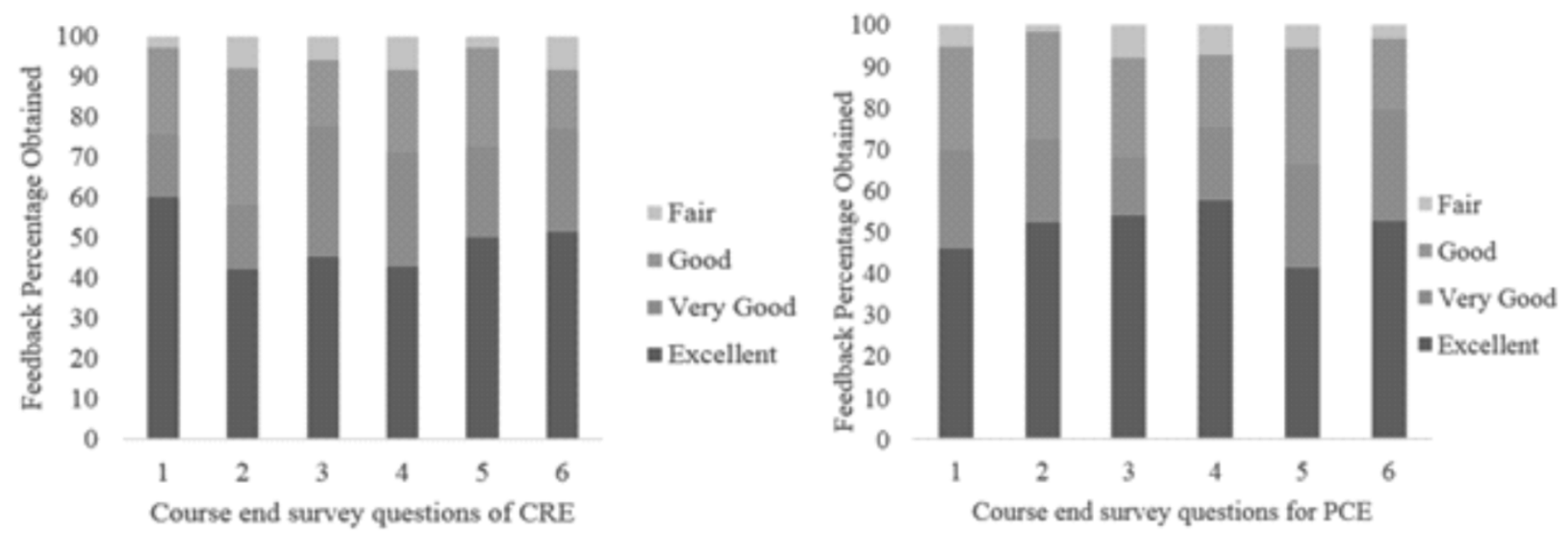

Fig. 1: Feedback on course end survey for CRE and PCE

Table 9: Course end survey on Chemical Reaction Engineering

\begin{tabular}{|l|l|}
\hline \multicolumn{2}{|c|}{ Course end survey on Chemical Reaction Engineering } \\
\hline 1 & $\begin{array}{l}\text { Able to formulate and analyze rate equations for different reactions using suitable mechanism } \\
\text { for reaching a sustainable conclusion }\end{array}$ \\
\hline 2 & $\begin{array}{l}\text { Able to analyze and interpret the data to determine rate equation and estimate the performance } \\
\text { equation for ideal system through virtual lab }\end{array}$ \\
\hline 3 & $\begin{array}{l}\text { Able to develop optimal operational conditions for ideal reactor with single and multiple } \\
\text { reactions }\end{array}$ \\
\hline 4 & $\begin{array}{l}\text { Able to predict reactor performance for non-isothermal conditions with consideration of } \\
\text { public health and safety during operations }\end{array}$ \\
\hline 5 & $\begin{array}{l}\text { Able to conduct experiments in teams to collect kinetic data from both ideal and non-ideal } \\
\text { reactors. }\end{array}$ \\
\hline 6 & $\begin{array}{l}\text { Able to interpret experimental data to estimate and provide valid conclusions in terms of their } \\
\text { kinetics and behavior for ideal and non-ideal reactors. }\end{array}$ \\
\hline
\end{tabular}




\section{Table 10: Course End survey on Process Control Engineering}

\begin{tabular}{|l|l|}
\hline \multicolumn{2}{|c|}{ Course end survey on Process Control Engineering } \\
\hline 1 & $\begin{array}{l}\text { Are you able to analyze and interpret data to formulate the transfer function, predict response of first and } \\
\text { second order systems \& predict their response }\end{array}$ \\
\hline 2 & $\begin{array}{l}\text { Were you able to understand different types of controllers and able to determine their response behavior's for } \\
\text { various inputs by working in teams }\end{array}$ \\
\hline 3 & Did the course help you to determine stability of linear control systems. \\
\hline 4 & $\begin{array}{l}\text { Were you able to design the system by using frequency response technique and determine the transient } \\
\text { response for servo and regulatory control systems }\end{array}$ \\
\hline 5 & $\begin{array}{l}\text { Able to conduct experiments in teams to determine the transfer function for various systems and determine } \\
\text { their response for various inputs. }\end{array}$ \\
\hline 6 & $\begin{array}{l}\text { The course developed your ability to engage in life-long learning of different control systems and also } \\
\text { communicate effectively. }\end{array}$ \\
\hline
\end{tabular}

given tasks, questioning, managerial and time managing capabilities are well managed and maintained.

Finally, feedback on the courses CRE and PCE is taken from the students by asking them to fill the course end survey form upon completion of the coursework. The questions were framed based on the course content taught and self study component as shown in Table $9 \& 10$ relating to their undertstanding of concepts, analyzing and intrepereting data, and their applications on their learning outcomes. The survey analysis is shown in Figure 1 for both the courses. Based on the course end survey it has enabled to evaluate the effectiveness of teaching and learning processes based on student feedback. Students rating has a great impact not only on quality of delivering the course but also on development of individuals teaching and as well improving quality of students learning by understanding their wants [14]. The number of students responded to this survey for both courses are 50 . Based on the survey, average of $49 \%$ of students found that the course to be excellent in determining, analysing and formulating rate expressions and predict the reactor performance and as well conduct experiments. Around $23 \%$ found to be very good, $22 \%$ good and $6 \%$ found the learning outcomes of the course to be fair enough.

In PCE course also 50 students have responded to the feedback and average of $51 \%$ found the course learning outcomes to be excellent, $21 \%$ found very good, $23 \%$ found to be good, and $5 \%$ found to be fair as shown in figure 1 . Most of them commented that this self-study component has made them ready to work in teams as well as individual and engaged them in life-long learning process. The student feedback survey data for my courses showed that student satisfaction was increasing gradually for self-study courses, representing that positive responses to student feedback on their learning outcomes is effective in enhancing student satisfaction and learning. It also shows students satisfaction and their insight of understanding the course material. Based on the insights gained from the research, we believe that by incorporating self-study component can effectively be used to assess student requirements, and strategically progress their skills. However, this paper is proposed towards innovative teaching and learning practices for creating a better student learning journey based on the course end survey through self-study component.

\section{Conclusion}

Results show that in both the courses CRE and PCE there is a substantial increase in the attainment of program outcomes by implementing self-study module to the engineering curriculum. Though the percentage increase in PCE coursework is around 12$15 \%$ in comparison to without implementing selfstudy component. On the other hand in CRE coursework there is a sufficient overall increase in progress of $22 \%$ compared to without implementing self study. It provides an overall performance and also in which specific field that students can perform better. It is seen clearly from the Table $7 \& 8$ that identifying, formulating, reviewing literature and analyzing engineering problems by reaching substantial conclusions has been attained by students. 
They had gained the ability to design solution or system modules or procedures that might need specific necessities for environmental considerations. It also gives us an understanding that they are focusing on the engineering solution in social and ecological circumstances plus the necessity for sustainable living. They have also learned how to function effectively, such as member in different groups and multidisciplinary situations. Providing technology to students has a slight effect on achievement in terms of building confidence in their abilities.. The course end survey analysis also shows that the students are really happy with this type of teaching learning practices by implementing self component. Considerable effort need to be put into core curriculum development, valuation reorganization, and formative assessment.

The influence of self-study on teachers and teaching counterparts includes regular changes from an instructor - centred lecture hall atmosphere to a more learner - focused accepting more effective use of technology tools. Learners gain self-confidence, selfrespect and better motivation in self- study circumstances. The relationship is up to the teaching learning progress and exists in order to develop the achievement of building confidence in them. If this one is acceptable the level of achievement can surely rise by varying the accomplishment technique. Thus comparatively the PO accomplishment is greater by introducing the self study module. Efficiency of teamwork is great in this aspect as its seen from both the courses. Though the results vary in strength, this study has found provision for all forms of active learning approaches by implementing self-study module. It is found that all students were engaged in all the events by which it can support us with valid conclusions about the performance of each student in various facets. Through this analysis special attention can be provided in the skills where students are requiring special care and attention. On the other hand without the self-study component it is found that overall performance is good enough but has no idea about their performances in individual aspects. So it gives a generalized idea about individual performance, their strengths and where they are not performing better. Apart from the conventional course work by which it could attain only few program outcomes, it is seen that by making this course as an integrated course where the teachers were able to satisfy multiple program outcomes by acting more likely as a facilitator. Learning competence by virtual laboratory methodology has improved undergraduate understanding capacity, simultaneously integrating student ownership, connecting experimentations to prior practices, and making students to develop higher order perceptive abilities that would deliver true analytical developments or practices.

\section{Acknowledgment}

The author likes to thank B.M.S College of Engineering, Bengaluru for this thoughtful implementation of self-study component in comprehensive course work.

\section{References}

[1] C. Anders R. Berg, V. Christina, B. Bergendahl, Bruno, Lundberg K.S. (2003) Benefiting from an open-ended experiment- A comparison of attitudes to, and outcomes of, an expository versus an open-inquiry version of the same experiment, Int. J. Sci. Educ., 25(3), 351-372.

[2] Rahman, N. A., Kofli, N. T., Takriff, M. S., \& Abdullah, S. R. S. (2011) Comparative study between open ended laboratory and traditional laboratory, In 2011 IEEE Global Engineering Education Conference (EDUCON), 40-44

[3] Noorhisham, T.K, Manal, I. \& Siti Zulikha, H. (2006) Implementation of Laboratory Courses in Second Year with Outcome Based Education, Proceeding of Teaching and Learning, Universiti Kebangsaan Malaysia, 94-106.

[4] Thomas, P.S. Fernandez, R.F., Manjon, B.F. (2009) Learning Team Work Skills in University Programming Courses, Computer \& Education. 53, 517-531.

[5] Ruthven, D.M. (1996) Chemical Engineering Education : A Personal View. Chem. Eng. Sci., $51(18), 3-4$.

[6] Vlachopoulos, D., Makri, A. (2017) The effect of games and simulations on higher education: a systematic literature review. Int J Educ Technol High Educ 14, 22.

[7] Muhamad, M., Zaman, H.B., Ahmad, A.(2010) Virtual laboratory for learning biology - a preliminary investigation, World. Acad. Sci. Eng. Technol. 6(71), 775-778. 
[8] Cook, D.A. (2007) Web-based learning: pros, cons and controversies, Clin. Med. 7, 37-42.

[9] Defanti, T. A., \& Brown, M. D. (1991). Visualization in scientific computing. In Advances in Computers, 33, 247-307.

[10] Sirisha Nallakukkala, Shabnam Siddiqui and Soumen P. (2018) Impact of Integrating SelfStudy Module in Chemical Engineering Course, Journal of Engineering Education Transformations , 32(2), 82-89.

[11] Radhamani, R., Sasidharakurup, H., Sujatha, G., Nair, B., Achuthan, K., \& Diwakar, S. (2014) Virtual labs improve student's performance in a classroom. In International Conference on ELearning, E-Education, and Online Training, 138-146.
[12] Jadhav, M. R., Kakade, A. B., Jagtap, S. R., \& Patil, M. S. (2020) Impact assessment of outcome based approach in engineering education in India. Procedia Computer Science, 172, 791-796.

[13] Cunningham, C. M., C. P. Lachapelle, R. T. Brennan, C. S. A. Tunis, and C. A. Gentry. (2020) The impact of engineering curriculum design principles on elementary students' engineering and science learning." Journal of Research in Science Teaching 57(3), 423-453.

[14] Hall, H. (2014) Using end-of-course student survey data to investigate faculty effectiveness. Christian Business Academy Review, 9, 107112. 